again to the level it originally occupied. Once more the skill of the surgeon, and, indeed, his reputation, is to be measured by the chronometer, and with the aid of the latest scientific-and popular-invention, the kinematograph, the powers of various men are to be judged of by the rapidity of their work. Not only so, but these records are to be handed down to posterity, and the operator is to be made to feei that he is not merely pitted against his contemporaries, but against all the surgeons of the future in this and all other countries. May it not follow as a matter of course that we shall vie with one another as to the rate at which we can open the abdomen, tear out the tumour, and sew all up again before the accusing film can have run half its course? Unfortunately the kinematograph will not record the aftercondition of the patient, or the deaths which will inevitably follow from secondary or consecutive hæmorrhage, sepsis, or the miseries due to new adhesions, fæcal fistula, and the like. Rapidity in operative work is to be made a fetish, to which we shall all, for a time at least, have to bow.

All, I say, but that is not so. Level-headed surgeonsand they are the majority-will, I am certain, refuse. Rapidity, like all other things which carry with them this possibility of fetishism, is a good thing-a thing to be aimed at in its due proportion. Its opposite-dawdling or fumbling - is most strongly to be avoided, to be reprobated. But rapidity is good only when used in its true and fitting relation to other things. Always the main end to be kept in view is the sound and perfect restoration to health of the patient; and we must get that, or as near to that as possible, by the use of all these means in their due relation to one another.

The risks of undue rapidity-of racing-are many. Consecutive hæmorrhage is one of the most likely to occur. I watched carefully the reproduction of a hysterectomy by kinematograph at Edinburgh, and one of the things which struck me most forcibly was the extraordinary behaviour of the vessels in the abdominal wall. One stroke of the operator's knife and the abdominal cavity was open, one wipe down by the assistant with a piece of lint and all bleeding from the cut edges ceased. To go no further, what became of those vessels? Not a single pressure forceps was placed, not a vessel was ligatured, but there was no further bleeding - from those parts at least. I appeal to any surgeon who has ever done abdominal section if this is credible? If all parts are to be treated in the same way death from peritonitis afterwards are certain to be many. Clark and Waterhouse have shown that the peritoneum can deal with bacteria to a great extent if it is clean, but if any appreciable clots of blood are left behind or find later entrance peritonitis is promptly set up by the septic changes induced in such clots, where bacteria find a fitting breeding ground and immunity from rapid absorption and phagocytosis. Vessels treated in this lightning fashion will certainly bleed afresh when the force of the circulation recovers itself after the patient has returned to bed, when all is closed up and the mischief can progress unseen until it is tor late to remedy. Will the kinematograph be re-introduced into the sick room and record for us the gasping, restless tossing of the exsanguine victim who is bleeding to death into her own abdominal cavity ; or the hurried, anxious-often, alas : uselessgroping of the surgeon with imperfect aid and light for the vessel now retracted into the subperitoneal tissues, or hidden under constantly increasing clot-that vessel which might so easily have been safely and finally secured in the morning had not the surgeon been racing against time in his devotion to the latest fetish of all-rapidity.

No protest can, I conceive, be too forcible against this new development of our art. Quick, nervous, prompt work is most desirable, but as all good things are liable to abuse, and such abuse is detestable in proportion to the very excellence of the thing abused, so racing in operative work is certain to entail results which will be as deplorable as those produced by careful rapidity are admirable. In surgery, as in everything else, a due perception of the proper perspective of things is absolutely necessary to produce perfect work.

Manchester.

TIVERTON INFIRMARY AND Dispensary. - The annual meeting of this institution was held recently under the presidency of Sir John Heathcote-Amory. The report showed that 1293 patients had been treated. The Victoria Wards, opened in Angust last by Lady Northcote, were now used by patients.

\section{EIGHTY SUCCESSIVE CASES OF STACKE'S OPERATION.}

BY PERCY JAKINS, M.D. DURH.,

SURGHON TO THE CENTRAL LONDON THROAT AND RAR HOSPITAL.

THE following consecutive series of 80 cases in which I have performed the radical mastoid operation (Stacke's) in cases of chronic suppurative otitis media serves to illustrate the symptoms demanding the performance of that operation and the beneficial results that may be expected. It should be premised that in all cases the procedure must be considered exploratory until the cavity of the antrum has been exposed, and by no method that I know can the medical man foretell with certitude what will be revealed. Broadly speaking, Stacke's operation consists in laying open the mastoid antrum and any diseased mastoid cells connected with it, opening the aditus leading from the antrum to the attic of the tympanum, cutting away all orerhanging bone, removing the posterior wall of the osseous meatus, and in some cases removing the malleus and the incus. All morbid products, such as cholesteatoma, pus, granulations, and diseased bone, are then removed, the cavity is thoroughly cleansed and disinfected, the cartilaginous meatus slit, and the upper and lower flaps are cut away. This series of 80 cases could be increased to 124 by inclusion of 44 cases of Schwartze's operation, a procedure of similar import except that the posterior osseous wall of the meatus is left intact. All these additional cases have resulted in recovery. It should also be added that concurrently my colleague, Dr. Dundas Grant, has had a similar series of cases of something like equal number. I think I may say that the success of both of us has been largely due to mutual conference and coöperation.

The indications for the performance of the operation are various. Together with persistence of purulent discharge one or other of the following symptoms was presented by these patients previously to operation: pain in the affected ear or corresponding side of the head, vertigo, nausea, vomiting, and general malaise; in some cases there were mental lassitude and a sullen demeanour. In most of them one or more of the following conditions was present: polypi or granulations in the tympanum, tenderness over the mastoid process, swelling of the meatus, bulging downwards of the posterior superior wall of the meatus and the adjacent part of Shrapnell's membrane, facial paralysis, caries of the ossicles or dead bone felt by the probe in the walls of the cavum tympani. The symptoms and physical conditions mentioned were rarely found singly but were mostly grouped in varying proportions. In every case the necessity for the operation was fully proved by the discovery of granulations, cholesteatoma, or necrosed bone, in the antrum or in the surrounding parts. In several of the cases it was necessary in the course of the operation to lay bare the dura mater in the middle fossa of the skull, to a greater or less extent, by the removal of a lamina of necrosed bone in the roof of the antrum. For the same reason the groove of the lateral sinus also was sometimes exposed in taking away a small piece of its bony wall. It was only occasionally that the mastoid cells became involved and required to be dealt with.

In recommending the operation the question of the effect upon the hearing power was naturally of but secondary consideration. It is, however, gratifying to report that audition was seldom rendered worse by the performance of the operation, while in some cases it was materially improved, probably owing to the removal of the accumulations of pus, granulations, and cholesteatomatous material which bad filled the tympanum and so prevented the sound waves from reaching the labyrinth.

An examination of the appended table shows that out of the 80 patients operated on 45 were females and also that in 49 cases the left was the ear affected. The preponderance of the female sex among the cases cannot be explained, for it is contrary to the statistics of the hospital with regard to all diseases of the ear, both acute and chronic. The preference for the left ear is in accordance with what is generally noted with regard to deafness, but especially in cases accompanied with any degree of acuteness of inflammation. Lennox Browne ${ }^{1}$ found that in 32 cases of othæmatuma the left ear

1 Othæmatoma, or the Insane Ear, West Riding Asylum Medical Reports, vol. v., 1875. 
Eighty Successive Cases of Stacke's Operation: Tabolar Statemen's.

\begin{tabular}{|c|c|c|c|c|c|c|c|c|}
\hline No. & Sex. & Age. & Ear. & Duration. & $\begin{array}{l}\text { Symptoms previously to } \\
\text { operation. }\end{array}$ & $\begin{array}{l}\text { Date of } \\
\text { operation. }\end{array}$ & Remarks. & Result. \\
\hline 1 & F. & 20 & R. & 18 years. & Recurrent polypi. & $\begin{array}{l}\text { Oct. 13th, } \\
1896 .\end{array}$ & $\begin{array}{l}\text { Granulation tissue and cheesy matter } \\
\text { in the antrum. }\end{array}$ & Cured. \\
\hline 2 & F. & 6 & L. & - & Pain, nausea, and giddiness. & Oet. 31st. & Antrum contained granulation tissue. & " \\
\hline 3 & F. & 27 & L. & - & Pain and giddiness. & $"$, & $\begin{array}{l}\text { Granulation tissue and cheesy } \\
\text { matter; dura mater exposed in the } \\
\text { middle fossa. }\end{array}$ & $s$ \\
\hline 4 & M. & 10 & R. & - & Headache and mental dulness. & Nov. 20th. & $\begin{array}{l}\text { Foetid pus in the antrum and granu- } \\
\text { lation tissue. }\end{array}$ & $"$ \\
\hline 5 & F. & 25 & $\mathbf{R}$ & 8 years. & Recurrent polypi. & $\begin{array}{l}\text { Feb. } 5 \text { th } \\
1897\end{array}$ & Cholesteatoma in the antrum. & $"$ \\
\hline 6 & F. & 17 & R. & 12 & Recurrent polypi. & March 5th. & $\begin{array}{l}\text { Granulation tissue in the antrum; } \\
\text { lateral sinus exposed. }\end{array}$ & ", \\
\hline 7 & F. & 19 & L. & 15 & $\begin{array}{l}\text { Recurring polypi, pain, and } \\
\text { giddiness. }\end{array}$ & "12th. & $\begin{array}{l}\text { Antrum was very large, full of } \\
\text { granulation tissue. }\end{array}$ & $s$, \\
\hline 8 & F. & 13 & L. & $"$ & Swelling over the mastoid ; pain. & May 6th. & $\begin{array}{l}\text { Mastoid cells, antrum, and attic were } \\
\text { full of granulation tissue and pus. }\end{array}$ & $"$ \\
\hline 9 & F. & 12 & R. & ", & $\begin{array}{l}\text { Pain, giddiness, and recurring } \\
\text { polypi. }\end{array}$ & , 13th. & Cholesteatoma in the antrum. & $n$ \\
\hline 10 & M. & 14 & L. & ", & Swelling over the mastoid ; pain. & June 4th. & $\begin{array}{l}\text { Pus and granulation tissue in the } \\
\text { mastoid cells and antrum; the incus } \\
\text { was removed. }\end{array}$ & 一 \\
\hline 11 & F. & 23 & R. & 17 & Pain, nausea, and giddiness. & " 8th. & $\begin{array}{l}\text { Mastoid cells and antrum contained } \\
\text { pus and granulation tissue ; the incus } \\
\text { was removed. }\end{array}$ & Cured. \\
\hline 12 & $\mathbf{F}$ & 25 & L. & ", & Recurrent polypi and pain. & "18th. & $\begin{array}{c}\text { Antrum was deep; granulation } \\
\text { tissue. }\end{array}$ & 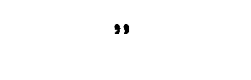 \\
\hline 13 & F. & 29 & I. & 20 & Pain and giddiness. & July 16th. & $\begin{array}{l}\text { Antrum was very deep; granulation } \\
\text { tissue. }\end{array}$ & $"$ \\
\hline 14 & M. & 13 & L. & - & Pain and recurring polypi. & "20th. & $\begin{array}{l}\text { Antrum was full of granulation } \\
\text { tissue. }\end{array}$ & $"$ \\
\hline 15 & M. & 7 & I. & 14 days. & $\begin{array}{l}\text { Sinus over the mastoid leading } \\
\text { into the antrum. }\end{array}$ & August 3rd. & $\begin{array}{l}\text { Antrum was full of granulation } \\
\text { tissue and cholesteatoma. }\end{array}$ & ", \\
\hline 16 & F. & 32 & $\mathbf{L}$. & 14 years. & $\begin{array}{l}\text { Facial paralysis, vomiting, and } \\
\text { pain. }\end{array}$ & Oct. 21st. & $\begin{array}{l}\text { Pus and granulation tissue in } \\
\text { antrum. }\end{array}$ & $"$ \\
\hline 17 & F. & 17 & R. & 15 & Nausea, pain, and giddiness. & Nov. 19th. & $\begin{array}{l}\text { Granulation tissue and cholesteatoma } \\
\text { in antrum. }\end{array}$ & 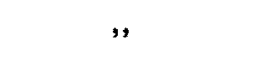 \\
\hline 18 & F. & 25 & R. & 12 & Pain, giddiness, and nausea. & "30th. & $\begin{array}{l}\text { Pus and gramulation tissue ; dura } \\
\text { mater of the middle fossa and lateral } \\
\text { sinus were exposed. }\end{array}$ & ", \\
\hline 19 & P. & 11 & L. & 8 months. & $\begin{array}{l}\text { Recurring polypi, pain, and facial } \\
\text { paralysis. }\end{array}$ & $"$ & $\begin{array}{l}\text { Mastoid cells were necrosed ; antrum } \\
\text { was full of granulation tissue ; } \\
\text { lateral sinus was exposed. }\end{array}$ & $\begin{array}{l}\text { Facial paralysis. } \\
\text { Cured. }\end{array}$ \\
\hline 20 & M. & 28 & I. & 20 years. & $\begin{array}{l}\text { Recurring polypi, extreme pain, } \\
\text { nausea, and giddiness. }\end{array}$ & Dec. 6th. & $\begin{array}{l}\text { Full of granulation tissue ; lateral } \\
\text { sinus covered with granulation } \\
\text { tissue and thrombosed ; left internal } \\
\text { jugular filled with pus. }\end{array}$ & $\begin{array}{l}\text { Died Jan. 6th, } \\
\text { 1898. }\end{array}$ \\
\hline 21 & $\mathbf{F}$ & 40 & I. & 38 & $\begin{array}{l}\text { Irritability, giddiness, nausea, } \\
\text { shivers, and pain. }\end{array}$ & $\begin{array}{l}\text { Jan. 18th, } \\
1898 .\end{array}$ & $\begin{array}{l}\text { Antrum was very deep; cholestea- } \\
\text { toma. }\end{array}$ & Cured. \\
\hline 22 & M: & 13 & L. & 12 & Polypi ; recurring facial paralysis. & March 15th. & $\begin{array}{l}\text { Full of granulation tissue; lateral } \\
\text { sinus was exposed. }\end{array}$ & $\begin{array}{l}\text { Facial paralysis. } \\
\text { Cured. }\end{array}$ \\
\hline 23 & F. & 28 & L. & 20 & Nausea, pain, and giddiness. & April 19th. & $\begin{array}{l}\text { Granulation tissue and cholestea- } \\
\text { toma; necrosed bone. }\end{array}$ & $\begin{array}{l}\text { Facial paralysis. } \\
\text { Well in nine } \\
\text { months. }\end{array}$ \\
\hline 24 & F. & 36 & R. & 25 & $\begin{array}{l}\text { Pain, shivering, vomiting, and } \\
\text { giddiness. }\end{array}$ & $"$ & Granulation tissue. & $\begin{array}{l}\text { Facial paralysis. } \\
\text { Well in six } \\
\text { months. }\end{array}$ \\
\hline 25 & $\mathbf{F}$. & 10 & L. & 6 weeks. & $\begin{array}{l}\text { Mastoid swelling ; fistulous open- } \\
\text { ing leading into the antrum. }\end{array}$ & "26th. & $\begin{array}{l}\text { Granulation tissue: lateral simus } \\
\text { covered with granulation tissue. }\end{array}$ & Cured. \\
\hline 26 & N. & 30 & $\mathbf{R}$. & 25 years. & $\begin{array}{l}\text { Recurrent polvpi and repeated } \\
\text { attacks of giddiness. }\end{array}$ & $"$ & $\begin{array}{l}\text { Antrum deep; full of granulation } \\
\text { tissue and cholesteatoma. }\end{array}$ & $"$ \\
\hline 27 & F. & 17 & I. & 1 year. & Pain, sickness, and polypi. & May 24th. & Antrum filled with granulation tissue. & ", \\
\hline 28 & F. & 13 & L。 & $2 \frac{1}{2}$ years. & $\begin{array}{l}\text { Semi-unconscions ; head well re- } \\
\text { tracted; bulging of the posterior } \\
\text { superior meatal wall. }\end{array}$ & June 15th. & $\begin{array}{l}\text { Cerebellar abscess. (Published in the } \\
\text { Journal of Laryngology, October, } \\
\text { 1899.) }\end{array}$ & " \\
\hline $2 \varepsilon$ & F. & $1 \frac{3}{6}$ & L. & $\begin{array}{c}12 \\
\text { months. }\end{array}$ & $\begin{array}{l}\text { Polypi, mastoid swelling, and } \\
\text { necrosed bone. }\end{array}$ & "18th. & $\begin{array}{l}\text { Disease of the whole temporul bone; } \\
\text { antrum was full of granulation } \\
\text { tissue and cholesteatoma. }\end{array}$ & $"$ \\
\hline 30 & M. & 9 & L. & - & Mastoid swelling. & July 9th. & $\begin{array}{l}\text { Mastoid cells full of pus, also antrum, } \\
\text { and attic, with cholesteatoma. }\end{array}$ & ", \\
\hline 31 & F. & 15 & $\mathbf{L}$. & 5 years. & Pain, nausea, and giddiness. & "19th. & $\begin{array}{l}\text { Mastoid cells and antrum full of } \\
\text { granulation tissue; lateral sinus } \\
\text { exposed. }\end{array}$ & , \\
\hline 32 & M. & 10 & $\mathbf{R}$ & - & $\begin{array}{l}\text { Mastoid swelling; sinus in the } \\
\text { bone leading to the antrum. }\end{array}$ & $\Rightarrow 26 \mathrm{th}$ & $\begin{array}{l}\text { Carious bone in the mastoid cells } \\
\text { antrum enlargea, containing pus and } \\
\text { cholesteatoma. }\end{array}$ & $"$ \\
\hline 33 & $\mathbf{M}$ & 22 & L. & - & $\begin{array}{l}\text { Stenosis of the meatus, pain, and } \\
\text { giddiness. }\end{array}$ & August 16th. & $\begin{array}{l}\text { Antrum filled with pus and granu- } \\
\text { lation tissue. }\end{array}$ & $"$ \\
\hline 34 & F. & 19 & L. & 3 years. & Facial paralysis. & "s & $\begin{array}{l}\text { Antrum full of cholesteatoma; } \\
\text { incus was removed. }\end{array}$ & $"$ \\
\hline 35 & M. & 18 & L. & - & $\begin{array}{l}\text { Delirious, rigors, swelling over } \\
\text { the mastoid, and great pain. }\end{array}$ & $" \quad 20$ th. & $\begin{array}{l}\text { Pus over the mastoid and in the } \\
\text { antrum; extradural abscess. }\end{array}$ & $\begin{array}{l}\text { Died } \\
\text { 22nd. }\end{array}$ \\
\hline
\end{tabular}


Eighty Successive Cases of Stacke's Operation : Tabular Statement.

\begin{tabular}{|c|c|c|c|c|c|c|c|c|c|}
\hline No. & Sex. & Age. & Ear. & \multicolumn{2}{|c|}{ Duration. } & $\begin{array}{l}\text { Symptoms previously to } \\
\text { operation. }\end{array}$ & $\begin{array}{l}\text { Date of } \\
\text { operation. }\end{array}$ & Remarks. & Result. \\
\hline 36 & $\mathbf{M}$. & 23 & L. & \multicolumn{2}{|c|}{3 weeks. } & Mastoid swelling. & Sept. 3rd. & $\begin{array}{l}\text { Full of granulation tissue filling the } \\
\text { antrum, and also found on the } \\
\text { lateral sinus. }\end{array}$ & Cured. \\
\hline 37 & $\mathbf{M}$ & 8 & L. & \multicolumn{2}{|c|}{4 years. } & $\begin{array}{l}\text { Mastoid swelling, sinus in the } \\
\text { bone leading to the antrum, and } \\
\text { pain. }\end{array}$ & Oct. 5th. & $\begin{array}{l}\text { Mastoid cells and antrum full of pus } \\
\text { and granulation tissue. }\end{array}$ & $"$ \\
\hline 33 & F. & 20 & L. & 16 & ", & Pain, vomiting, and giddiness. & Nov. 8th. & $\begin{array}{l}\text { Antrum full of pus and cholestea- } \\
\text { toma. }\end{array}$ & $"$ \\
\hline 39 & F. & 15 & L. & 2 & $"$, & $\begin{array}{l}\text { Subject to epileptic fits; no } \\
\text { cause. }\end{array}$ & " 8th. & $\begin{array}{l}\text { Small granulations and carious bone } \\
\text { in the attic. }\end{array}$ & $\begin{array}{l}\text { Cured. Fits not } \\
\text { improred. }\end{array}$ \\
\hline 40 & $\mathbf{M}$. & 8 & L. & 7 & $"$ & $\begin{array}{l}\text { Polypi recurring, drowsiness, and } \\
\text { pain. }\end{array}$ & , 29tb. & $\begin{array}{l}\text { Antrum full of large granulation } \\
\text { tissue, also attic. }\end{array}$ & Cured. \\
\hline 41 & F. & 6 & L. & 3 & $"$ & $\begin{array}{l}\text { Fistulous opening in the mastoid } \\
\text { leading to the antrum. }\end{array}$ & Dec. 12th. & $\begin{array}{l}\text { Mastoid cells and antrum full of } \\
\text { granulation tissue; granulations } \\
\text { over the lateral sinus. }\end{array}$ & $\because$ \\
\hline 42 & M. & 8 & L. & 2 & $"$ & Mastoid swelling. & , 17th. & $\begin{array}{l}\text { Antrum full of granulation tissue } \\
\text { and pus. }\end{array}$ & , \\
\hline 43 & M. & 8 & $\mathbf{R}$. & 7 & $"$ & $\begin{array}{l}\text { Mastoid swelling; sinus leading } \\
\text { to the antrum. }\end{array}$ & $\begin{array}{l}\text { Jan. 2nd, } \\
1899 .\end{array}$ & $\begin{array}{l}\text { Pus and granulation tissue in the } \\
\text { mastoid cells and antrum. }\end{array}$ & $"$ \\
\hline 44 & F. & 13 & L. & 2 & $"$ & Recurring polypi. & Jan. 31st. & $\begin{array}{l}\text { Antrum full of cholesteatoma and } \\
\text { lateral sinus exposed. }\end{array}$ & " \\
\hline 45 & M. & 7 & L. & 3 & $"$ & Pain, nausea, and giddiness. & Feb. 2nd. & $\begin{array}{l}\text { Antrum very deep; granulation } \\
\text { tissue. }\end{array}$ & $"$ \\
\hline 46 & F. & 20 & R. & 17 & ", & Giddiness and pain. & " 21st. & Antrum full of granulation tissue. & ." \\
\hline 47 & M. & 13 & L. & 8 & $"$ & $\begin{array}{c}\text { Mastoid swelling, pain, and } \\
\text { nausea. }\end{array}$ & $\begin{array}{l}\text {,, 25th. } \\
\text { March 2nd. } \\
\text {, 10th. }\end{array}$ & $\begin{array}{l}\text { Antrum opened, full of pus and } \\
\text { granulation tissue. } \\
\text { Extradural abscess. } \\
\text { Lateral sinus thrombosis ; internal } \\
\text { jugular vein tied. }\end{array}$ & $\begin{array}{l}\text { Died March } 21 \text { st. } \\
\text { Empyema of the } \\
\text { chest. }\end{array}$ \\
\hline 48 & M. & 19 & R. & & - & $\begin{array}{l}\text { Mastoid swelling; fistulous open- } \\
\text { ing leading to the antrum. }\end{array}$ & $\begin{array}{l}\text { Feb, 28th, } \\
1899 \text {. }\end{array}$ & $\begin{array}{l}\text { Pus in the antrum and granulation } \\
\text { tissue. }\end{array}$ & Cured. \\
\hline 49 & $\mathbf{M}$. & 24 & R. & & - & Pain, giddiness, and nausea. & March 14th. & $\begin{array}{l}\text { Antrum very deep; pus and granula- } \\
\text { tion tissue. }\end{array}$ & $"$ \\
\hline 50 & $\mathbf{M}$. & 19 & $\mathbf{R}$ & $12 y$ & yezrs. & $\begin{array}{l}\text { Recurring polypi, pain, and } \\
\text { drowsiness. }\end{array}$ & April 11th. & $\begin{array}{l}\text { Carious bone removed, antrum full of } \\
\text { granulation tissue. Lateral sinus } \\
\text { exposed. }\end{array}$ & $"$ \\
\hline 51 & F. & 22 & $\mathbf{R}$. & 10 & $"$ & Pain, giddiness, and nausea. & May 9th. & $\begin{array}{l}\text { Dura mater of the middle fossa } \\
\text { exposed; antrum full of granulation } \\
\text { tissue. }\end{array}$ & - \\
\hline 52 & $\mathbf{M}$. & 32 & $\mathbf{R}$. & 10 & $"$, & Giddiness, pain, and nausea. & , 16th. & Antrum contained cholesteatoma. & - \\
\hline 53 & $\mathbf{F}$. & 14 & $\mathbf{R}$. & 10 & $"$ & Pain and nausea. & , 30th. & $\begin{array}{l}\text { Fistulous opening into the antrum ; } \\
\text { lateral sinus completely exposed. }\end{array}$ & - \\
\hline 54 & F. & 26 & L. & 80 & , & $\begin{array}{l}\text { Had attacks of epileptic con- } \\
\text { vulsions. }\end{array}$ & June 2nd. & $\begin{array}{c}\text { Antrum } \\
\text { tissue. }\end{array}$ & Cured. \\
\hline 55 & F. & 33 & R. & 20 & $"$ & $\begin{array}{l}\text { Depression of spirits, pain, giddi- } \\
\text { ness, and nausea. }\end{array}$ & " 6th. & Antrum full of cholesteatoma. & "• \\
\hline 56 & $\mathbf{M}$. & 20 & R. & & - & $\begin{array}{l}\text { Mastoid swelling, pain, and giddi- } \\
\text { ness. }\end{array}$ & " 11th. & $\begin{array}{l}\text { Antrum full of pus and granulation } \\
\text { tissue; extradural abscess. }\end{array}$ & $"$ \\
\hline 57 & M. & 29 & L. & & - & Pain, nausea, and giddiness. & July 18th. & $\begin{array}{l}\text { Antrum and attic full of granulation } \\
\text { tissue and cholesteatoma. }\end{array}$ & - \\
\hline 58 & M & 28 & L. & 205 & years. & Pain and recurrent polypi. & , $25 \mathrm{th}$ & Antrum contained granulation tissue. & \\
\hline 59 & $\mathbf{F}$. & 37 & $\mathbf{R}$. & 5 & , & Pain, nausea, and giddiness. & August 1st. & $\begin{array}{l}\text { Antrum and attic full of choleste- } \\
\text { atoma. }\end{array}$ & Cured. \\
\hline 60 & F. & 32 & R. & & - & Facial paralysis and pain. & ", 22nd. & $\begin{array}{l}\text { Antrum and attic full of granulation } \\
\text { tissue and cholesteatoma; lateral } \\
\text { sinus was exposed. }\end{array}$ & " \\
\hline 61 & M. & 24 & $\mathbf{R}$. & $2 y$ & years. & $\begin{array}{l}\text { Pain, vomiting, giddiness, and } \\
\text { bulging of the meatal wall. }\end{array}$ & , & Temporo-sphenoidal abscess. & $\bullet$ \\
\hline 62 & F. & 15 & L. & & - & Swelling over the mastoid ; pain. & \# 29 th. & $\begin{array}{l}\text { Fistulous opening into the antrum, } \\
\text { pus, and granulation tissue. }\end{array}$ & 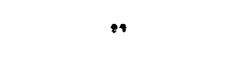 \\
\hline 63 & M. & 40 & L. & $30 y$ & years. & Pain, nausea, and giddiness. & " 31st. & Antrum full of granulation tissue. & , \\
\hline 67 & F. & 16 & L. & 11 & $"$ & Vertigo, sickness, and pain. & Sept. 5th. & $\begin{array}{l}\text { Antrum contained granulation tissue } \\
\text { and necrosed bone. }\end{array}$ & " \\
\hline 65 & F. & 26 & R. & 20 & $"$ & Recurrent polypi. & " 26th. & $\begin{array}{c}\text { Antrum contained granulation } \\
\text { tissue. }\end{array}$ & $"$ \\
\hline 66 & $\mathbf{M}$. & 41 & L. & 11 & 3 & Pain, papillitis, and giddiness. & $"$ & $\begin{array}{l}\text { Antrum contained granulation tissue } \\
\text { and cholesteatoma. }\end{array}$ & $"$ \\
\hline 67 & $\mathbf{F}$. & 16 & R. & $6 \mathrm{mc}$ & onths. & Pain and giddiness. & Oct. 3rd. & $\begin{array}{l}\text { Antrum contained a cholesteato- } \\
\text { matous cyst. }\end{array}$ & $"$ \\
\hline 68 & M. & 37 & L. & $12 \mathrm{~J}$ & years. & Pain and recurring polypi. & $" \quad "$ & $\begin{array}{l}\text { Antrum contained granulation tissue } \\
\text { and cholesteatoma. }\end{array}$ & $\therefore$ \\
\hline 69 & F. & 28 & L. & 18 & $"$ & Pain, nausea, and giddiness. & $" 10$ th. & $\begin{array}{l}\text { Antrum was deep and contained } \\
\text { granulation tissue and cholestea- } \\
\text { toma; duramater of the middle fossa } \\
\text { was exposed. }\end{array}$ & $"$ \\
\hline 70 & M. & 24 & L. & 20 & $"$ & Pain, vertigo, and nausea. & $"$ & $\begin{array}{l}\text { Antrum was large and contained a } \\
\text { brown fluid and cholesteatoma; dura } \\
\text { mater of the middle tossa was } \\
\text { exposed. }\end{array}$ & $" *$ \\
\hline 71 & $\mathbf{M}$. & 30 & L. & & ", & Giddiness. & " 17th. & $\begin{array}{l}\text { Antrum contained granulation tissue } \\
\text { and cholesteatoma. }\end{array}$ & $"$ \\
\hline
\end{tabular}


Eighty Successive Cases of Stacke's Operation: Tabular Statement.

\begin{tabular}{|c|c|c|c|c|c|c|c|c|}
\hline No. & Sex. & Age. & Ear. & Duration. & $\begin{array}{l}\text { Symptoms previously to } \\
\text { operation. }\end{array}$ & $\begin{array}{l}\text { Date of } \\
\text { operation. }\end{array}$ & Remarks. & Result. \\
\hline 72 & F. & 29 & L. & 25 years. & Pain, nausea, and giddiness. & Oct. 17th. & $\begin{array}{l}\text { Antrum contained granulation tissue ; } \\
\text { dura mater of the middle fossa was } \\
\text { exposed. }\end{array}$ & Cured. \\
\hline 73 & M. & 62 & R. & 4 months. & $\begin{array}{c}\text { Mastoid swelling, pain, and } \\
\text { nausea. }\end{array}$ & " 31st. & $\begin{array}{l}\text { Fistulous opening leading to the } \\
\text { antrum full of pus and granulation } \\
\text { tissue. }\end{array}$ & ", \\
\hline 74 & F. & 29 & L. & 12 years. & Pain, giddiness, and nausea. & $" \quad "$ " & $\begin{array}{l}\text { Antrum full of granulation tissue } \\
\text { and oholesteatoma. }\end{array}$ & , \\
\hline $75^{\prime}$ & F. & 23 & L. & 20 & Pain, giddiness, and nausea. & Nov. 7th. & $\begin{array}{l}\text { Antrum contained granulation } \\
\text { tissue. }\end{array}$ & Recovery. \\
\hline 76 & F. & 30 & $\mathbf{L}$. & 20 & Pain, giddiness, and nausea. & " $23 r d$. & $\begin{array}{l}\text { Mastoid cells and antrum contained } \\
\text { granulation tissue. }\end{array}$ & , \\
\hline 77 , & M. & 13 & R. & 10 & Pain, giddiness, and nausea. &,$\quad 11$ & $\begin{array}{l}\text { Antrum very deep, contained granu- } \\
\text { lation tissue. }\end{array}$ & " \\
\hline 78 & M. & 5 & L. & - & Mastoid swelling and pain. & , 28th. & $\begin{array}{l}\text { Fistulous opening leading into the } \\
\text { antrum containing granulation } \\
\text { tissue. }\end{array}$ & $"$ \\
\hline 79 , & M. & 26 & $\mathbf{R}$. & 14 years. & Pain, nausea, and giddiness. & , & $\begin{array}{l}\text { Antrum was very deep and contained } \\
\text { granulation tissue. }\end{array}$ & $"$ \\
\hline 80 & F. & 24 & L. & 18 & Pain, nausea, and giddiness. & Dec. 12th. & $\begin{array}{l}\text { Antrum contained granulation } \\
\text { tissue; lateral sinus exposed. }\end{array}$ & , \\
\hline
\end{tabular}

For the notes of these cases I am indebted to my colleague, Mr. Chichele Nourse, who has more especially followed their progress.

was affected in 19 instances, in both ears in 11, and the right ear only in two cases. In those cases in which both were affeoted the left ear was first attacked. His explanation of the fact is the nearer position of the left common carotid to the heart and the more direct and less impeded arterial supply to the left than to the right side of the head, this observer noting, also, that arachnoid cysts so frequent in that form of mental disease in which othæmatomata may be expected are more commonly found on the left than on the right hemisphere of the brain. The average age of the patients is between 20 and 21 years, the youngest subject being 14 months old. The average duration of the suppurative disease in those cases where it could be ascertained was $12 \frac{1}{2}$ years.

Turning now to the symptoms exhibited by patients before the operation, persistent suppuration of the middle-ear was present in all and pain was very commonly complained of. 39 of the patients were troubled with attacks of vertigo, in 19 there were recurrent polypi, and in 17 there was swelling orer the mastoid process. Facial paralysis was present before the operation in five cases and mental disturbance was noted six times. In two cases of old-standing suppuration (Cases 39 and 54) the operation was mainly undertaken in the hope of curing the epileptic fits to which the patient had recently become subject. Though the conditions discovered proved that the operation was abundantly justified the fits showed no improvement in Case 39 , but a complete cure resulted in Case 54. The original disease was complicated by septic phlebitis of the lateral sinus and the internal jugular vein in two instances and by extradural abscess in three. Cerebral abscess was found once and cerebellar abscess once. At the time of the operation dead bone was discovered and removed in seven cases. In 11 a fistulous opening led from the surface of the mastoid process to the antrum. The middle fossa of the skull was exposed six times during the operation and the groove of the lateral sinus was laid bare in some part of its course 14 times. The cerebral and cerebellar abscesses were successfully located and drained and in one fatal case the internal jugular vein was tied. In two cases facial paralysis appeared after the operation, but in both it disappeared again within nine months. Except in those patients--three in number-whose condition was almost beyond hope on admission the results of the operation were zuniformly successful.

With regard to the results of this operation the mortality in my hands has been practically nil, for the only three deaths reported were brought into the hospital in a very advanced stage of pyæmic poisoning. In the successful cases the threatening symptoms quickly disappeared, the change from sullen stupidity to lively intelli. gence being very noteworthy. Occasionally a slight purulent discharge continues for some time; but owing to the freedom with which the adjacent cavities have been placed in communication with the now very wide meatus no accumulations can possibly occur, and the whole tympanum, antrum, and attic gradually become soundly healed and can be inspected at any time by means of a speculum. In conclusion, my experience leads me to the opinion that it is safer to operate at an early period of suppurative disease, should there exist any of the enumerated indications for it, rather that wait until the processes have had time to produce signs of a more threatening character, and possibly to infect some of the intra-cranial contents.

Harley-street, $W$.

\section{CONSANGUINEOUS MARRIAGE AND DEAF-MUTISM.}

BT ALFRED H. HUTH, AUTHOR OF "THE MARRIAGE OF NEAR KIN."

THE question of the intermarriage of the deaf and its consequences has excited attention almost ever since deafmutism itself has been studied, and very various opinions have been expressed upon the subject. On the one side is the remarkable fact that frequently none of the children of deaf parents are deaf, while on the other side we have the indisputable fact that deafness is as strongly inherited as any other disease of the nervous system. In short, this is another example of the now generally accepted axiom that inheritance equals the sum of the ancestry divided by the number of the ancestors, and since there is, at present at least, no deaf race of human beings so the inheritance of deafness must be proportionately uncertain. In the absence of reliable statistics it is difficult to ascertain how far this nheritance is likely to be intensified by the intermarriage of the deaf. Such marriages are not very common in Europe. In the United States, however, where for the last half-century a great deal of attention has been paid to the education of the deaf and where consequently they have been more intimately brought together, so much intermarriage has gone on as to excite the alarm of many observers. In 1884 Dr. Graham Bell, the well-known creator of the Volta Bureau of Washing. ton, published his "Memoir upon the Formation of a Deaf Variety of the Human Race," and now Dr. Fay comes forward with an elaborate inquiry into the result of "Marriages of the Deaf in America." By means of circulars and other investigations Dr. Fay bas collected a grand total of 3078 marriages, sufficiently reported for conclusions to be 